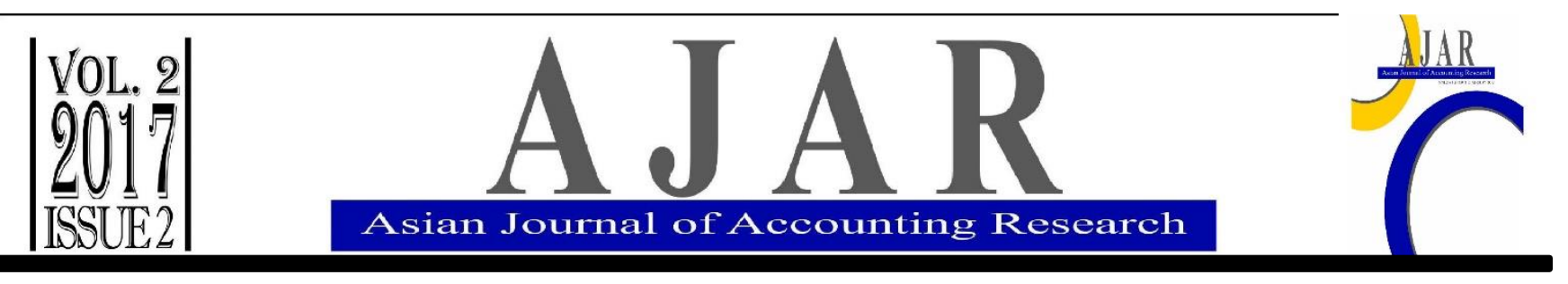

\title{
Do Reputable Companies Produce a High Quality of Financial Statements?
}

\author{
Iman Harymawan ${ }^{1,2}$, Dewi Nurillah ${ }^{1}$ \\ 1 Universitas Airlangga \\ ${ }^{2}$ Corresponding author: harymawan.iman@feb.unair.ac.id
}

ARTICLE INFO

Article history:

Available online 31 August 2017

Keywords:

Corporate Reputation, Financial

Reporting Quality, Earnings Quality, Developing Country

\begin{abstract}
The purpose of this study is to examine the relationship between corporate reputation and earnings quality. This study uses a sample of 1,092 firm year observations from 273 firm listed companies on the Indonesia Stock Exchange from 2013 to 2016, except for the financial industry. We uses a public measure, "100 Top Emiten" by Investor magazine, as a proxy for corporate reputation, while earnings quality is measured by calculating the absolute value of discretionary accrual. Growth of assets, firm size, leverage and profitability are used as control variables in this study. Multiple linear regression analysis is used to test the research hypothesis. The results of the regression in this study indicate that corporate reputation has a positive and significant relationship with earnings quality. This indicates that a reputable company will be encouraged to produce an earnings quality in an effort for the company to maintain investor confidence in the company, so that the company's image and reputation can be maintained. Earnings management in this study was calculated using crosssectional method instead of time series method. Cross-sectional method is a method by comparing the financial data of a company with a company or other similar industries, whereas the time series method uses the comparison of financial data in a period with the previous period by analyzing what happens behind the trend figures on a company.
\end{abstract}

\section{Introduction}

Previous research related to the determinants of the quality of earnings has been widely applied (Francis et al., 2008; Luchs et al., 2009; Gberegbe et al., 2017). The determinants are CEO reputation, corporate reputation, firm size, the market to book ratio, board size, extent of independent directors, board of directors and the frequency of the board meetings, and the type of external auditor. The number of these studies indicates the importance of earnings quality on corporate financial reporting. Widjaja and El Maghviroh (2011) state that earnings quality is an accounting profit that can reflect the actual financial performance of a company. The lower the information contained in the accounting profit, the lower quality of the accounting profits. The low earnings quality can certainly mislead investors and creditors in assessing the company's true financial performance.

This study would like to examine the relationship between corporate reputations on earnings quality, because corporate reputation is acknowledged as one of the determinants of earnings quality. Further, empirical evidence shows that the result on the association between corporate reputation and earnings quality are inconsistent. Adzor and Igbawase (2014), who compare the earnings quality of reputable companies with nonreputable companies in Nigeria, show that Nigerian companies with a higher reputation ranked by the Forbes West African Top 25 companies do not have a significant superior earnings quality than non-reputable companies of similar size in the same industry, while the results of research conducted by Luchs et al. (2009) indicate that firms with superior reputation also have superior earnings quality.

Francis et al. (2008) states that users of financial statements consider corporate reputation as important in assessing the quality of financial statements. Users of financial reports are convinced that reputable companies will have high accountability, credibility and trust. As such, values will be reflected in the rules, structure and implementation of the company's operational activities. Cao et al. (2011), who examine the relationship between a company reputation and possible restatement of financial statements, find that firms with higher reputation value tend not to experience misstatements in their financial statements.

This is in line with our hypothesis, that companies with good reputation will be driven to have high earning quality as an effort to maintain investor confidence in the company. Such reputable companies would be interested in recruiting reliable, professional managers, directors and auditors to ensure accountability. The 
existence of an audit committee and internal supervision to supervise and monitor the performance of management is expected to minimize the possibility of information asymmetry between managers (agents) and owners (principal), which can provide opportunities for managers to make earnings management. The low level of earnings management leads to the high quality of earnings on the company's financial statements being achieved. The high quality of earnings is expected to increase investor confidence in the company, so that the image and reputation of the company will be maintained.

To investigate this issue, we use sample of listed firms from Indonesia. To the knowledge of the researcher, there is no study that investigates the impact of corporate reputation on earnings quality of listed firms in Indonesia. We use a cross-sectional study to explicitly consider earnings quality of listed firms (different sectors) in Indonesia. In our analysis, we use a sample of 1,092 firm year observations from 273 firms listed on the Indonesia Stock Exchange from 2013 to 2016. We use the public measure, "100 Top Emiten" by Investor magazine, as a proxy for corporate reputation, while earnings quality is measured by calculating the absolute value of discretionary accrual-Modified Jones (1991). Growth of assets, firm size, leverage and profitability are used as control variables in this study. Our result indicates that earnings quality of reputable companies increases due to low earnings management practices, but decreases as earnings management practice improves.

The remainder of this paper is structured as follows: Section 2 develops the research hypotheses; Section 3 describes the sample and variables; Section 4 specifies the empirical models and present the research result; Section 5 summarizes the paper.

\section{Literature Review}

Based on the agency theory, the company owner (principal) often uses the profit available in the financial statements to measure the company's operational performance performed by the manager (agent). Although, in reality, managers (agents) as internal parties are more aware of the conditions within the company than external parties and will use the opportunity of information asymmetry to manage earnings opportunistically and manipulate earnings in the financial statements to look better, although not in accordance with actual company conditions. Actions of earnings management will certainly affect the quality of earnings reported by the company. Whereas the profit information in the financial statements is an important aspect for stakeholders to assess the financial health of the company, because the qualified profit is profit that can explain the actual financial condition of the company and reflects the continuity of the business in the future.

Investors and creditors, when assessing the quality of financial statements, are more interested and trust to invest in big companies that have a good reputation. Fombrun (1996, p.72) states that the corporate reputation is a representation of past perceptions and future prospects that describe the performance of the company as a whole. Users of financial reports are confident that reputable companies will have high accountability, credibility and trust; thus, values will be reflected in the rules, structure and implementation of the company's operational activities. McLaughlin et al. (1996) state that the most admired companies tend to be profitable and grow rapidly. In line with McLaughlin et al. (1996), Roberts and Dowling (2002) suggest that reputable companies may have a cost advantage, because people prefer to work for reputable companies, and they work harder.

Previous research on corporate reputation provides a theoretical background for measuring company reputation (Fombrun and Shanley, 1990; Aaker, 1997; Davies and Chun, 2002; Cravens et al., 2003). In this study, companies included in the "100 Top Emiten", as stated by Investor magazine, are used as a proxy for corporate reputation. The ranking of the company's reputation by the magazine has gone through a series of long selection processes by selecting fundamental and technical performance of well-regarded companies.

Therefore, it can be assumed that a company with a good reputation will have a low earnings management, so that the earnings quality will be high. This is in line with the results of research conducted by Adıgüzel and Özbay (2017) on the relationship between corporate reputation and real activities management, which shows that reputable firms in developing country are less likely to manipulate real activities. Based on the description that has been described above, the hypothesis of this study is as follows:

Hypothesis. The corporate reputation has a positive effect on earnings quality.

\section{Empirical Framework}

\subsection{Sample and Data}

The sample of research is all companies listed on Indonesia Stock Exchange (IDX) year 2013-2016 except the financial industry. This study uses secondary data obtained from the annual financial statements of firms listed on the IDX for the year ended 31 December, and from the list of reputable companies category based on "100 Top Emiten" by Investor magazine. All financial data obtained from the IDX website (www.idx.co.id) will then be compared with data obtained from the rating of Investor magazine. Based on these criteria, the total sample used in this study is 1,092 observations consisting of 273 companies in each period of financial statements. Table 1 shows the sample used in the research obtained by purposive sampling method. 
Table 1

Sample Selection and Industry Distribution

Panel A : Sample Selection Total

Firms listed on the IDX

Except:

Firms missing data

Financial industry

Observation data available in one event (each year)

Total event observation data ( $x 4$ years)

\section{Panel B : Industry Distribution}

\begin{tabular}{clr}
\hline Code & Industry & Total \\
\hline 1 & Agriculture & 19 \\
2 & Mining & 32 \\
3 & Basic Industry and Chemicals & 59 \\
4 & Miscellaneous Industry & 36 \\
5 & Consumer Goods Industry & 35 \\
6 & Property, Real Estate and Building Construction & 51 \\
7 & Infrastructure, Utilities and Transportation & 41 \\
\hline & Observation data available in one event (each year) & 273 \\
\hline & Total event observation data (x4 years) & $\mathbf{1 , 0 9 2}$ \\
\hline
\end{tabular}

\subsection{Measurement of Corporate Reputation}

We use a public measure, "100 Top Emiten" by Investor magazine, as a proxy for corporate reputation. We used dummy variables by coding 1 if the company is included in the ranking list in the magazine and 0 if not. Following prior studies (Luchs et al., 2009; Adıgüzel and Özbay, 2017; Latif et al., 2017), we included the growth of assets, firm size, leverage and profitability as a control variables.

\subsection{Measurement of Earnings Quality}

We measure earnings quality by investigating the level of absolute value of discretionary accruals (DA) using Modified Jones Model (1991). The use of absolute value discretionary accrual in this study serves as a determinant of whether or not and how much earnings management activity is undertaken by the company by not considering the negative or positive direction. Subsequently, the absolute value of DA is multiplied by -1 to show the value of earnings quality directly. This is because the absolute value of discretionary accrual is viewed as an inverse measure of earnings quality, which means that the lower absolute value of DA suggests higher earnings quality. The calculation of DA with Modified Jones model is as follows:

1) Determine the total accrual

$$
T A_{i, t}=N I_{i, t}-C F O_{i, t}
$$

2) Determine the parameter value $\alpha, \beta_{1}$, dan $\beta_{2}$ using the Jones Model

$$
T A_{i, t}=\alpha+\beta_{1} \Delta R E V_{i, t}+\beta_{2} \Delta P P E_{i, t}+\epsilon_{i, t}
$$

Then, to scale the data, all of those variables are shared with the previous year's assets

$$
\frac{T A_{i, t}}{A_{i, t-1}}=\alpha\left(\frac{1}{A_{i, t-1}}\right)+\beta_{1}\left(\frac{\Delta R E V_{i, t}}{A_{i, t-1}}\right)+\beta_{2}\left(\frac{\Delta P P E_{i, t}}{A_{i, t-1}}\right)+\epsilon_{i, t}
$$

3) Compute the value of NDA

$$
N D A_{i, t}=\alpha\left(\frac{1}{A_{i, t-1}}\right)+\beta_{1}\left(\frac{\Delta R E V_{i, t}}{A_{i, t-1}}-\frac{\Delta R E C_{i, t}}{A_{i, t-1}}\right)+\beta_{2}\left(\frac{\Delta P P E_{i, t}}{A_{i, t-1}}\right)
$$

4) Determine the discretionary accruals

$$
D A_{i, t}=T A_{i, t}-N D A_{i, t}
$$

Where:

$T A_{i, t} \quad=$ total accruals of firm $\mathrm{i}$ in year $\mathrm{t}$

$N_{i, t} \quad=$ net income of firm $\mathrm{i}$ in year $\mathrm{t}$

$\mathrm{CFO}_{i, t} \quad=$ cash flow from operation of firm $\mathrm{i}$ in year $\mathrm{t}$

$N D A_{i, t} \quad=$ non discretionary accrual of firm $\mathrm{i}$ in year $\mathrm{t}$

$D A_{i, t} \quad=$ discretionary accrual of firm $\mathrm{i}$ in year $\mathrm{t}$

$A_{i, t-1} \quad=$ total assets of firm i in year $\mathrm{t}-1$

$\triangle R E V_{i, t} \quad=$ industry i's change in revenue between year ( $\left.\mathrm{t}-1\right)$ and year $\mathrm{t}$

$\triangle R E C_{i, t} \quad=$ industry i's change in receivables between year ( $\left.\mathrm{t}-1\right)$ and year $\mathrm{t}$

$\triangle P P E_{i, t} \quad=$ industry i's gross property, plant and equipment at the end of year $\mathrm{t}$ 
Table 2

Variables Measurement

\begin{tabular}{|c|c|c|c|}
\hline & Variable & Proxy & Data Source \\
\hline $\begin{array}{l}\text { Earnings } \\
\text { Quality }\end{array}$ & $E Q$ & $D A_{i, t}=\left(T A_{i, t}-N D A_{i, t}\right) x-1$ & IDX \\
\hline $\begin{array}{l}\text { Corporate } \\
\text { Reputation }\end{array}$ & $C R$ & $\begin{array}{l}1 \text { if the company is included on the " } 100 \text { Top Emiten" by } \\
\text { Investor magazine and } 0 \text { if not }\end{array}$ & $\begin{array}{l}\text { Investor } \\
\text { Magazine }\end{array}$ \\
\hline $\begin{array}{l}\text { Growth of } \\
\text { assets }\end{array}$ & GROWTH & GROWTH $=\frac{\left(\text { Total }_{\text {Assets }} \text { Tot, }_{i}-\text { Total }_{\text {Assets }}, t-1\right)}{\text { Total Assets }_{i, t}}$ & IDX \\
\hline Firm size & FIRMSIZE & FIRM SIZE $=\log$ Total Assets & IDX \\
\hline Leverage & LEVERAGE & LEVERAGE $=\frac{\text { Total Liabilities }}{\text { Total Assets }}$ & IDX \\
\hline Profitability & $R O A$ & $R O A=\frac{\text { Net Income }}{\text { Total Assets }}$ & IDX \\
\hline
\end{tabular}

\section{Empirical Results}

\subsection{Preliminary Results}

Descriptive statistics analysis aims to describe the variables used without comparing the relationship between variables. Here are the descriptive statistics of the research variables on all samples used in the study after the data has been winsorized:

Table 3

Descriptive Statistics

\begin{tabular}{lccccc}
\hline Variable & Mean & Median & Standard Deviation & Minimum & Maximum \\
\hline EQ & -0.091 & -0.066 & 0.087 & -0.480 & -0.001 \\
GROWTH & 0.087 & 0.083 & 0.171 & -0.518 & 0.663 \\
FIRMSIZE & 12.472 & 12.454 & 0.679 & 10.993 & 13.982 \\
LEVERAGE & 0.523 & 0.493 & 0.373 & 0.045 & 2.728 \\
PROFITABILITY & 0.037 & 0.033 & 0.096 & -0.346 & 0.359 \\
\hline
\end{tabular}

Based on Table 3, the following conclusions can be drawn. First, the mean value of EQ of -0.091 shows the average level of earnings quality is very low because it is below 0 . Furthermore, the mean value of GROWTH of 0.087 indicates the average growth of assets used in this study, while the average size of the company used in this study amounted to 12.472 , which is indicated by the mean value of FIRMSIZE. The average amount of assets of companies financed by debt in this study tend to be small, so is good for the financial health of the company. This is indicated by the mean value of LEVERAGE of less than 1, which is 0.523. The value of debt to asset ratio of more than 1 indicates the greater the amount of debt used for asset investment to generate profits for the company. In this study, the average company is still able to generate profits by using the total existing assets. This is indicated by a positive mean value of ROA of $3.7 \%$.

Researchers used the Independent-Sample T-Test in order to identify the difference in average earnings quality, as indicated by the EQ between those companies considered to be reputable companies according to the Investor magazine survey and those which were not. The variables used for the independent sample T-Test is the company's reputation, which is divided into two groups: reputable and non-reputable companies. Below are the results of the tests using the Independent-Sample T-Test on the results of observation and sample calculation:

Table 4

Independent-Sample T-Test

\begin{tabular}{lcccc} 
& \multicolumn{2}{c}{ INV 100 } & diff & t-value \\
& $\mathrm{N}=246$ & $\begin{array}{c}\text { Non Reputable } \\
\mathrm{N}=846\end{array}$ & & \\
\hline EQ & -0.080 & -0.094 & $0.014^{* *}$ & 2.181 \\
GROWTH & 0.139 & 0.072 & $0.067^{* * *}$ & 5.484 \\
FIRMSIZE & 12.946 & 12.334 & $0.613^{* * *}$ & 13.452 \\
LEVERAGE & 0.470 & 0.539 & $-0.068^{* *}$ & -2.535 \\
PROFITABILITY & 0.088 & 0.022 & $0.066^{* * *}$ & 9.901 \\
\hline Significance & & &
\end{tabular}

Significance Level ${ }^{*} 10 \%{ }^{* *} 5 \%{ }^{* * *} 1 \%$ 
Table 4 shows the Independent-Sample T-Test results on average earnings quality and some control variables, such as GROWTH, FIRMSIZE, LEVERAGE and PROFITABILITY. The results of the IndependentSample T-Test analysis show that the mean value of EQ of firms of reputed companies by Investor magazine is -0.080 and -0.094 in non-reputable firms. This indicates that the mean EQ of firms of reputed magazines by Investor magazine is greater than the mean EQ on firms that are not reputable at a significance level of $5 \%$.

Pearson Correlation test was performed to determine the initial indication of direction and strength between two variables (Acock, 2008, p. 180) used in this study. Table 5 shows the results of Pearson Correlation Test against the variables EQ, INV100, GROWTH, FIRMSIZE, LEVERAGE and PROFITABILITY:

Table 5

Pearson Correlation Test

$\begin{array}{lcccccc} & (1) & (2) & (3) & (4) & (5) & (6) \\ \text { (1) EQ } & 1.000 & & & & & \\ \text { (2) INV100 } & & & & & \\ & 0.066^{* *} & 1.000 & & & & \\ \text { (3) GROWTH } & (0.029) & & & & & \\ & -0.164^{* * *} & 0.164^{* * *} & 1.000 & & & \\ \text { (4) FIRMSIZE } & (0.000) & (0.000) & & & & \\ & 0.021 & 0.377^{* * *} & 0.159^{* * *} & 1.000 & & \\ \text { (5) LEVERAGE } & (0.491) & (0.000) & (0.000) & & & \\ & -0.099^{* * *} & -0.077^{* *} & -0.148^{* * *} & 0.042 & 1.000 & \\ \text { (6) PROFITABILITY } & (0.001) & (0.011) & (0.000) & (0.168) & & \\ & 0.066^{* *} & 0.287^{* *} & 0.378^{* * *} & 0.084^{* * *} & -0.335^{* * *} & 1.000 \\ & (0.028) & (0.000) & (0.000) & (0.006) & (0.000) & \end{array}$

$p$-values in parentheses ${ }^{*} p<0.1,{ }^{* *} p<0.05,{ }^{* * *} p<0.01$

Based on the Pearson Correlation Test, earnings quality has a positive and significant relation to independent variable, which is INV100, and control variable, which is profitability, and has a negative and significant relationship to control variables of growth and leverage. However, earnings quality has a positive and not significant relationship to firm size.

\subsection{Main Results}

Regression test was conducted to determine the effect of corporate reputation on the quality of earnings at the company listed on the Indonesia Stock Exchange in the period 2013-2016. The researchers suspect that there is a positive relationship between corporate reputation and earnings quality because a reputable company will want to protect and retain the company's existing reputation by encouraging companies and managers to limit earnings management activities that can affect the quality of corporate profits. So, if the hypothesis is true, then expected result of regression in this research indicates the existence of a positive and significant relation between corporate reputations with earnings quality.

In the relationship between growth of assets and the earnings quality, the researchers suspect that there is a negative relationship, because asset growth will have an impact on the management decision in determining the capital structure of the company, thus making the earnings quality to be low. Regarding the firm size relationship with earnings quality, the researchers suspect there is a positive relationship, because relatively large companies will be more careful in reporting their financial condition to the public, by showing more detailed information and transparence so that the company will use less earning management and earnings will become more qualified.

In the leverage relationship with earnings quality, we suspect that there is a negative relationship because firms with high leverage levels will have a tendency to earn earnings management to reduce credit risk and the earnings management action will certainly make the earnings quality to be low. Regarding the relationship between profitability with the earnings quality, the researchers suspect there is a positive relationship, because companies that have been able to generate profits with assets used (high ROA), no longer need to practice earnings management to generate high profits, so the earnings become more qualified.

The regression results show a positive and significant influence between dependent variable (EQ) and independent variable (INV100) and control variable (PROFITABILITY). There is a negative and significant influence between EQ with GROWTH and LEVERAGE. However, there was a positive and insignificant influence between EQ and FIRMSIZE in this study.

Regression using robust method can produce outliers that have little impact on estimation of regression coefficient, so that it can overcome the problem of heteroscedasticity. Based on Table 6, the regression result with robust method shows the change of significance level compared to the previous multiple linear regression. LEVERAGE variable that was initially significant at level $1 \%$ becomes significant at level $5 \%$ and the variable 
PROFITABILITY initially significant at level $1 \%$ becomes significant at level $10 \%$. Then result of robust regression still shows significant influence between dependent variable (EQ), independent variable (INV100) and control variable (GROWTH, LEVERAGE AND PROFITABILITY). However, there was no significant influence between EQ and FIRMSIZE in this study.

Below are the results of regression testing on the results of observation and sample calculation:

$\mathrm{EQ}=\alpha+\beta_{1}$ Reputation $+\beta_{2}$ Growth $+\beta_{3}$ Firmsize $+\beta_{4}$ Leverage $+\beta_{5}$ Profitability $+\epsilon$

Table 6

Result of Regression

\begin{tabular}{lccc}
\hline Variable & Predicted Sign & $\mathrm{EQ}$ & $\mathrm{EQ}$ \\
& & $(1)$ & $(2)$ \\
\hline INV100 & + & $0.011^{*}$ & $0.011^{*}$ \\
& & $(1.65)$ & $(1.76)^{*}$ \\
GROWTH & - & $-0.117^{* * *}$ & $-0.117^{* * *}$ \\
& & $(-7.22)$ & $(-4.08)$ \\
FIRMSIZE & + & 0.004 & 0.004 \\
& & $(1.01)$ & $(1.02)$ \\
LEVERAGE & - & $-0.022^{* * *}$ & $-0.022^{* *}$ \\
& & $(-3.04)$ & $(-2.44)$ \\
PROFITABILITY & + & $0.094^{* * *}$ & $0.094^{*}$ \\
INTERCEPT & & $(3.01)$ & $(1.92)$ \\
& & $-0.127^{* *}$ & $-0.127^{* *}$ \\
\hline R-squared & & $(-2.51)$ & $(-2.55)$ \\
$N$ & & 0.059 & 0.059 \\
\hline
\end{tabular}

Significance Level * $10 \%{ }^{* *} 5 \%$ *** $1 \%$

The hypothesis in this study states that the corporate reputation has a positive and significant impact on earnings quality. In line with the hypothesis, the regression results in this study showed that the corporate reputation variable (INV100) showed a positive regression coefficient of 0.011 with earnings quality and had a significance level of $10 \%$. Therefore, it can be concluded that there is a positive and significant influence between the company's reputations with the quality of profit.

This suggests that a reputable company will be increasingly motivated to minimize earnings management practices in an effort to maintain the corporate reputation and maintain investor confidence in the company. Higher earnings quality in reputable companies has been also proven by the Independent-Sample T-Test results. Independent-Sample T-Test shows that the mean value of EQ of reputable companies according to Investor magazine is -0.080 , whereas the mean value of $E Q$ in non-reputable companies is -0.094 .

\section{Conclusions}

Based on the results and discussion above, the conclusion which can be obtained from this study related to the relationship between the corporate reputation and earnings quality is that corporate reputation has a positive and significant relationship with earnings quality. So it can be said that a company with a good reputation will be encouraged to minimize earnings management practices, resulting in higher profits. This is in accordance with research conducted by Luchs et al. (2009) which states that a reputable company will have a high profit quality. Therefore, the hypothesis in this study which states that the reputation of the company has a positive and significant relationship with the quality of earnings is acceptable.

Variable control in this research showed that growth and leverage have negative and significant influence with earnings quality, while profitability has a positive and significant influence with earnings quality. Firm size in this study also has a positive effect with earnings quality only, firm size has no significant effect on earnings quality.

\section{References}

Aaker, J.L. (1997). Dimensions of brand personality. Journal of Marketing Research, 34, pp, 347-356.

Acock, A.C. (2008). A gentle introduction to Stata: Stata Press.

Adıgüzel, H. and Özbay, D. (2017). Corporate Reputation and Real Activities Management, Evidence from an Emerging Economy. Journal of Business \& Economic Policy,4(1).

Adzor, I. and Igbawase, A. (2014). Do Reputable Companies Have Superior Earnings Quality? International Journal of Innovative Research \& Development, 3.

Brigham, E and Joel, F.H. (2001). Manajemen Keuangan II. Jakarta: Salemba Empat.

Cao, Y., Myers, L. and Omer, T. (2011). Does Company Reputation Matter for Financial Reporting Quality? Evidence from Restatements. Contemporary Accounting Research, Forthcoming.

Cravens, K.., Oliver, E.G. and Ramamoorti, S. (2003). The reputation index: measuring and managing corporate reputation. European Management Journal, 21(2), pp. 201 - 212. 
Davies, G. and Chun, R. (2002). Gaps between the internal and external perceptions of the corporate brand. Corporate Reputation Review, 5(2-3), pp. 144-158.

Djamaluddin, S. (2008). Analisis Perbedaan Antara Laba Akuntansi dan Laba Fiskal terhadap Persistensi Laba, Akrual dan Aliran Kas pada Perusahaan Perbankan yang Terdaftar di Bursa Efek Jakarta. Jurnal Riset Akuntansi Indonesia, 11 (1), pp. 52-74.

Fombrun, C.J. and Shanley, M. (1990). What's in a name? Reputation building and corporate strategy. The Academy of Management Journal, 33(2), pp. 233 - 258.

Fombrun, C. (1996). Reputation: Realizing Value from the Corporate Image. Boston, MA: Harvard Business School Press.

Francis, J., Huang, A., Rajgopal, S. and Zang, A. (2008). CEO Reputation and Earnings Quality. Contemporary Accounting Research, 25 (1), pp. 109-47.

Gberegbe, F.B., Umoren, A., Peters, G.T. and Wege, L.G. (2017). Corporate Reputation and Earnings Quality of Listed Firms in Nigeria. Journal of Research in Business and Management, 5, pp. 14-22.

Ghosh, A. and D. Moon. (2010). Corporate Debt Financing and Earnings Quality. Journal of Business Finance and Accounting, 37, pp. 538-559.

Latif, K., Bhatti, A. Raheman, Abdul. (2017). Earnings Quality: A Missing Link between Corporate Governance and Firm Value. Business \& Economic Review, 9 (2), pp. 255-280.

Luchs, C., Stuebs, M. and Sun, L. (2009). Corporate Reputation and Earnings Quality. The Journal of Applied Business Research, 25(4).

Mashayekhi, B. and Bazaz, M. (2010). The Effects of Corporate Governance on Earnings Quality: Evidence from Iran. Asian Journal of Business and Accounting, 3(2), pp. 71-100.

McLaughlin, R. M., Ruback, R. and Tehranian, H. (1996). Does corporate quality matter? Working paper, Suffolk University.

Roberts, P. and Dowling, G. (2002). Corporate Reputation and Sustained Superior Financial Performance. Strategic Management Journal, 23(12), pp, 1077-1093.

Tan, H. (2007). Does the Reputation Matter? Corporate Reputation and Earnings Quality. Working paper, China Southwestern University of Finance and Economics.

Tong, Y.H. and Miao, B. (2011). Are Dividends Associated with the Quality of Earnings? Accounting Horizons, 25 (1), pp. 183-205.

Widjaja, F.P. and Maghviroh, R.E. (2011). Analisis Perbedaan Kualitas Laba dan Nilai Perusahaan Sebelum dan Sesudah adanya Komite Audit pada Bank Bank Go Public di Indonesia. The Indonesian Accounting Review, 1(2), pp. 117-134. 